Original article

\title{
3D printing applications towards the required challenge of stem cells printing
}

\author{
Mohd Javaid*, Abid Haleem \\ Department of Mechanical Engineering, Jamia Millia Islamia, New Delhi, India
}

\section{A R T I C L E I N F O}

\section{Keywords:}

3D printing

Additive manufacturing (AM)

Applications

Stem cells

Capabilities

Medical

\begin{abstract}
A B S T R A C T
Background: Additive Manufacturing (AM) technologies are innovative and are being applied successfully in the medical field as they provide the extensive capability of customisation. Here in this study, we have identified research papers on AM applications, specifically 3D printing in stem cells.

Aim of work: This study provides information to health professionals and helps them to solve different medical challenges in an effective manner which is not possible with the traditional method of stem cells fabrication. Materials and methods: Undertook the study through good research papers published on Stem cells on the applications of 3D printing which are also helpful to sort out different medical problems and their solution.

Result: This paper studies 3D printing technology in the context of stem cells fabrications, brief about the stem cells, its functions and its superior capabilities in the medical field. Paper identified thirteen significant stem cells applications achievable through the practical applications of 3D printing. Finally, the paper provides a brief discussion on the future potential of this technology for the printing of stem cells.

Conclusions: 3D printed stem cells seem to have extensive applications in regenerative medicine for the treatment of various diseases. These cells help seed decellularisation of complete organs for regenerative medicine. This technology also applies to the reconstruction of heart valves and has excellent potential in valvular disease. These cells have higher capabilities to fulfil different medical requirements, but it is challenging to steer its growth as per the need of human kind. Scientists created 3D printed stem cells structure which can grow, and they have performed tissue regeneration experiments on them. Traditionally researchers produce 2D sheets of cells. Now, this technology introduces the fabrications in 3D with stem cells which can also be developed in the human body. 3D printing approach creates uniform building blocks of stem cells with precise and controlled growth and seems helpful to the human body for consistent tissue growth. Nevertheless, this is just a starting, and there is a long way to go for commercial printing of human body parts.
\end{abstract}

\section{Introduction}

3D printing is an innovative approach for the transplantation of cells which is further applicable for improved treatment of the patient. It accelerates tissue engineering through its innovative applications. 3D printing is an essential component of additive manufacturing (AM). 3D printed stem cells respond to specific growth factors which are transplanted directly for different injured tissue. These cells promote the potential for the regeneration of defect. Scientists have developed a wide variety of natural and synthetic materials which effortlessly combine cells with a biocompatible scaffold. These are used for better treatment of neurodegenerative disease. Stem cells create structural components to the skin, blood vessels and corneal tissues. These improve the regenerative activity of damaged bone and cartilage. ${ }^{1,2}$ There are different types of 3D printing technologies available. Mostly inkjet 3D printing technology is used to print stem cells, and these cells are added with other materials in the liquid form.

Stem cells require more study for enhancing its applications and understanding of control activities. Researchers have invented an innovative way to improve this process. ${ }^{3,4}$ They conducted numbers of the clinical trial for therapy and treatment in a specific condition. This technology has changed the detailed cellular structure based on Computer Tomography (CT), Magnetic Resonance Imaging (MRI) and other associated scanning technologies such as a 3D scanner. It improves the overall quality of patient life by reducing associated healthcare cost. Scientists have used 3D printing for making biological scaffold for

\footnotetext{
* Corresponding author.

E-mail addresses: mjavaid@jmi.ac.in (M. Javaid), ahaleem@jmi.ac.in (A. Haleem).

https://scholar.google.co.in/citations?user=rfyiwvsAAAAJ\&hl=en (M. Javaid), https://scholar.google.co.in/citations? user =4047148AAAAJ\&hl = en (A. Haleem)
} 
enabling the growth of the implanted tissue and found this viable for successful human clinical trials.

3D printing follows different steps like Medical imaging, Digital Imaging and Communications in Medicine (DICOM) format, and then preparation of 3D computer-aided design (CAD) model which is exported in standard triangulate language (STL) format to a 3D printer. Finally, we print the required medical parts. ${ }^{7}$

In the human body, stem cells can develop new specialised cells types which can replace cells and tissues lost/damaged. 3D printed stem cells consist of hydrogel or gelatin and living cells which are used in the form of ink and create a defined biological structure. ${ }^{8,9}$ This paper studies brief about stem cells and their major functions in the medical field. A brief description of additive manufacturing and 3D printing are provided. The applications of stem cells through the application of 3D printing are discussed. This paper studied the possibilities of 3D printing for stem cells to save the life of humanity.

\section{Research gap and research question of the paper}

Stem cells can heal damaged tissue, and it functions as source cells of the human body. These cells have the potential to grow new tissue and organs. Scientists use these cells for therapies of liver disease, macular degeneration, infertility, Parkinson disease, spinal cord injury, diabetes etc. The traditional technique for fabrications of stem cells is successful, but the main gap of the customisation, which is now well taken up by 3D printing technologies. ${ }^{10,11}$ This technology explores its potential in the field of stem cells printing as per the requirement of the customer and found works in different clinical applications and provided the capability to handle many critical situations of the patient. This study based paper addresses the following research questions:

RQ1: To brief about 3D printing technology and contributions in stem cells fabrication;

RQ2: to study different advancements of 3D printings through the input of stem cells;

RQ3: to review the concept of stem cells and describe their significant functions and capabilities for better treatment;

RQ4: to identify significant applications of stem cells through the use of 3D printing;

RQ5: to study limitations and future scope of 3D printing in stem cells.

\section{Stem cells}

Stem cells are unique cells of a human, having an extensive capability to develop different types of cells from muscle to brain cells. These cells are imaged by MRI, which helps to enhance the treatment. ${ }^{12,13}$ These are also used for the treatment of paralysis and alzheimer's disease. ${ }^{14-16}$ Researchers and practitioners use 3D printed stem cells to create building blocks which can be used to grow microorgans, testing of medications, performing tissue regeneration and undertake biological research. These are used to create embryoid bodies with high precision which can be grown in a controlled manner. Stem cells are used for the treatment and repair of damaged tissues.

Embryonic stem cells and adult stem cells are two main forms of stem cells. These stem cells are used for better treatment of bone marrow transplants. Scientists can quickly (Identify) develop stem cells using MRI. It is helpful for a clear understanding of how a cell behaves in the human body after implementation. 3D printing can create engineering cells to fight cancer and remove the cause of disease.

\section{Additive manufacturing (AM)}

Additive Manufacturing provides disruptive innovation in contemporary designing and manufacturing scenario. It uses different types of processes and technologies to build a part by adding material layer by layer technique with the input of CAD 3D digital models. AM technologies are classified into three sets as, namely 3D printing, 3D scanning and associated software for designing, scanning, printing and support. Input materials are in the form of powder, liquid and sheet materials depend upon the types of processes and technologies of additive manufacturing. Earlier AM technique was also called as Rapid Prototyping (RP) due to its rapid manufacturing of prototype. The applications of AM are in medical, dentistry, automobile, design and development of product/tools and production human tissues and organs. It is used to create lighter and stronger parts with a higher level of flexibility. AM provides extensive advantages of manufacturing complex geometries, improved performance, lesser wastage of raw materials and simplified fabrication process. ${ }^{17-19}$ The research is continuously carried out on employing stem cell-based therapies to reduce the diseases. AM aims to replace and generate organs and tissues with the help of mainly 3D printing technology sets as per customer requirement. Next section provides a brief description of 3D printing.

\section{3D printing}

3D printing is a disruptive innovation which is used to fabricate any products/implants/tissue/cells layer by layer directly from CAD digital data. This technology uses specialised materials and mixed cells to create 3D tissue. Hydrogel-based bioinks is used as a specialised material. This bioink is helpful for the maintenance of cells for printing. 3D printing technology is used to print stem cells in a hydrogel solution. Printed stem cells by this technology develop new life-sized tissue. Scientists \& researchers take advantages of this technology to improve diagnosis and treatment. The doctors and surgeon can now convert a new idea into a reality which improves the quality of the patient life. It can efficiently solve the different medical problem in an effective manner. ${ }^{20,21} 3 \mathrm{D}$ printing is used to fabricate following different types of cells and associated requirements:

- Adult stem cell

- Somatic cell

- Tissue engineering

- Embryonic stem cell

- Bone marrow transplant

First-time stem cells are created from "bio-ink" using a low-cost 3D printer. This process is feasible, which held their shape soft and keep stem cells alive. These cells keep alive at room temperature with the help of hydrogel. During the printing of stem cells, these can grow as per the requirements of the researcher. Now a day, it is used to print tissue by using bio-ink without growing cells separately. This technology forms a shape of the human cornea, and the entire printing process takes less time. The 3D printing technology for stem cells achieves high success rate in healthcare as discussed under:

\section{1. $3 D$ printing for stem cells}

There are millions of people having requirements of organs, and with an extensive shortage of organ donor, large numbers of peoples are not able to survive. Thus, to fulfil this crisis of organ donor, scientists and researchers are continuously working to develop 3D printing technologies which use stem cells as bio-ink. This technology quickly overtakes this unique challenge. 3D printing is the best technique for a better understanding of the complex architecture of blood vessels. It produces blood vessel as per required shape and size in lesser time and cost. $^{22,23}$ This technology can fulfil the demand for stem cells, which can survive and work properly. Different advancements of 3D printing are the fabrication of living body parts, biological components, reconstruction of jawbone from actual CT scan data and helpful for a blind person. 
Table 1

Different applications of stem cells through 3D printing.

\begin{tabular}{|c|c|c|c|}
\hline S No & Applications & Description & References \\
\hline 1 & Treatment of skin & $\begin{array}{l}\text { - One of the largest organs of the body is skin which is used to protect internal } \\
\text { organs (both soft and hard tissue) for the external environment } \\
\text { - 3D printing technology is now available to print skin and used for the restoration } \\
\text { of its physiologic function } \\
\text { - Stem cells provide effective therapy for a burn patient }\end{array}$ & $\begin{array}{l}\text { Blaeser et al., } 2016^{35} \text {; Haleem and Javaid, } \\
2019^{36} \text {; Wang et al., } 2019^{37} \text {; }\end{array}$ \\
\hline 2 & Regenerative medicine & $\begin{array}{l}\text { - Stem cells opens an innovative path in regenerative medicine } \\
\text { - These are applied for improving the treatment of nervous tissue, blood vessels, } \\
\text { bone and skin } \\
\text { - It develops a new method of repair, regrows and replacement of diseased cells } \\
\text { - This technique is implemented successfully for the production of artificial organs }\end{array}$ & $\begin{array}{l}\text { Faulkner-Jones et al., } 2015^{38} \text {; Nyberg et al., } \\
2017^{39} \text {; Li et al., } 2019^{40}\end{array}$ \\
\hline 3 & $\begin{array}{l}\text { Treatment of chronic heart } \\
\text { disease }\end{array}$ & $\begin{array}{l}\text { Doctors can now able to treat chronic heart disease from growing heart muscle } \\
\text { cells for the damaged heart } \\
\text { - Easily create heart muscle which is helpful for congestive heart failure treatment } \\
\text { - Stem cells are also used for other specific condition like narrowed arteries of the } \\
\text { heart, blood pressure and coronary artery disease }\end{array}$ & Zhou, $2017^{41}$; Sharafeldin et al., $2018^{42}$ \\
\hline 4 & $\begin{array}{l}\text { Custom made a living body } \\
\text { part }\end{array}$ & $\begin{array}{l}\text { - This technology quickly makes customised living body parts of 3D printed stem } \\
\text { cells } \\
\text { - Develop a life-sized organ-like structure } \\
\text { - Produce tissue which can easily flow oxygen and blood } \\
\text { - Produce segment of ear, jawbone and muscle tissue }\end{array}$ & Gao et al., $2015^{43}$; Yang et al., $2018^{44}$ \\
\hline 5 & Biological components & $\begin{array}{l}\text { - 3D printing quickly prints muscle cells which works like healthy muscles } \\
\text { - Enables a variety of applications like heart and brain tissues } \\
\text { - 3D printing efficiently undertakes the printing of human muscles, jawbones and } \\
\text { other body parts from digital 3D models } \\
\text { - It easily prints living tissues for regeneration which can further able to } \\
\text { accommodate blood vessels }\end{array}$ & Yeo et al., $2016^{45}$; Xu et al., $2018^{46}$ \\
\hline 6 & Growing Cartilage & $\begin{array}{l}\text { - } 3 \text { D printing is used to produce growing cartilage using stem cells } \\
\text { survival of the patient } \\
\text { - Researchers used stem cells to grow tissue and resemble cartilage which is } \\
\text { helpful to repair different body parts }\end{array}$ & $\begin{array}{l}\text { Goldshmid and Seliktar, } 2017^{47} \text {; Javaid and } \\
\text { Haleem, } 2018^{48}\end{array}$ \\
\hline 7 & Cardiac patches & $\begin{array}{l}\text { - Researchers reprogrammed the cells of the fatty tissue which can develop cell as } \\
\text { per the requirement of heart growth } \\
\text { - It consists of structural components, such as collagen and glycoproteins which } \\
\text { turn into a bioink and mixed with stem cells } \\
\text { - These stem cells help to creates cardiac patches which are helpful to save patient } \\
\text { life }\end{array}$ & $\begin{array}{l}\text { Chien and Shah, } 2012^{49} \text {; Yoo et al., } 2016^{50} \text {; } \\
\text { Vashistha et al., } 2019^{51}\end{array}$ \\
\hline 8 & Helpful blind person & $\begin{array}{l}\text { - In the current scenario, blindness is a big problem which can be somewhat taken } \\
\text { up by stem cells } \\
\text { - These cells have a promising therapeutic strategy of a patient suffering from } \\
\text { blindness diseases } \\
\text { - Stem cells are used to restore the vision of a patient with damaged corneas }\end{array}$ & Gu et al., $2016^{52}$; Placone and Engler, $2018^{53}$ \\
\hline 9 & Spinal injuries & $\begin{array}{l}\text { - Researchers created 3D printed neuronal stem cells which can be implanted in } \\
\text { the injury site } \\
\text { - It quickly prints silicone scaffold and neuronal stem cells } \\
\text { - 3D printed stem cells provide full recovery to the patient } \\
\text { - Stem cells derive cells to provide significant contributions during the repair of } \\
\text { spinal cord injury and replacement of nerve cells }\end{array}$ & $\begin{array}{l}\text { Kamei, } 2013^{54} \text {; Jamróz et al., } 2018^{55} \text {; } \\
\text { Cidonio et al., } 2019^{56}\end{array}$ \\
\hline 10 & Customised patient face & $\begin{array}{l}\text { - This technology is exciting and is used for making a customised patient face with } \\
\text { own natural tissue } \\
\text { - Results show is a reduction in operating time and outcomes } \\
\text { - Stem cells having the potential for the treatment of a wide range of face disease } \\
\text { and therapies }\end{array}$ & $\begin{array}{l}\text { Lou et al., } 2014^{57} \text {; O'Brien et al., } 2015^{58} \text {; } \\
\text { Kwon et al., } 2018^{59}\end{array}$ \\
\hline 11 & Fabrication of jawbone & $\begin{array}{l}\text { - A missing bone of the jaw is easily created from CT scan data } \\
\text { - This scan data helps to rebuild the shape required jaw as per patient match } \\
\text { - The implantation of this 3D printed jawbone helpful in the future clinical } \\
\text { scenario } \\
\text { - 3D printed stem cells are used to regenerate atrophic jaw bone which is further } \\
\text { helpful in accurate implantation of dental implants }\end{array}$ & Ouyang et al., $2016^{60}$; Lin et al., $2019^{61}$ \\
\hline 12 & Outer human ear & $\begin{array}{l}\text { - There is a high possibility to build complex-shaped outer part of the human ear } \\
\text { - A customised 3D printed ear is implanted easily in the skin of the patient } \\
\text { - This technology is almost closer to reality for human use which can fabricate } \\
\text { stable tissue of any shape and size }\end{array}$ & $\begin{array}{l}\text { Tasoglu et al., } 2013^{62} \text {; Javaid and Haleem, } \\
2019^{63} \text { Zhuang et al., } 2019^{64}\end{array}$ \\
\hline 13 & $\begin{array}{l}\text { 3D printed stem cells for } \\
\text { patients teeth }\end{array}$ & $\begin{array}{l}\text { - In the dentistry field, a dentist can easily implant 3D printed cell in the teeth of } \\
\text { patient mouth } \\
\text { - It can quickly create dental implants for replacement of damaged teeth and } \\
\text { repair of other injuries } \\
\text { - Stem cells are used for a clinical trial of making children teeth which can regrow } \\
\text { the damaged teeth tissue } \\
\text { - These cells having the potential for the full range of treatment of certain systemic } \\
\text { dental diseases }\end{array}$ & $\begin{array}{l}\text { Javaid and Haleem, } 2019^{65} \text {; Liao et al., } \\
2019^{66} \text {; Yi et al., } 2019^{67}\end{array}$ \\
\hline
\end{tabular}




\section{Functions of stem cells}

A wide variety of stem cells such as embryonic, mesenchymal and pluripotent stem cells are used for the regeneration of damaged tissues. Mesenchymal stem cells are isolated from different tissues, which include bone marrow, tonsil and adipose tissue. ${ }^{24,25}$ These are used for clinical trials and help cure various diseases of bone, cartilage, neuronal, cardiovascular and inflammatory. There are many different types of cell available in our body. Stem cells provide new cells for growth in the human body. ${ }^{26,27}$ Different functions of stem cells in medicine are as under:

- Stem cells are helpful to create new cells and tissues

- Used for research to understand the essential biological functions of a living being

- Helpful to study cell functions during any disease

- Used for therapy where replacement of damaged or lost cells is required

- Understanding the growth of our body

- Study the process of disease

- Study the effect of different drug

- Easily transplanted into the body to replace damaged or lost tissue

- Provide healthy blood to the body

- Better treatment of the patient

- Generate new skin for a burn patient

- Helpful for the patient eye to replace its damaged cell

\section{Capabilities of stem cells for treatment}

3D printing is an innovative technique used to combine cells, biomaterials and functional components into living tissue. ${ }^{28-30}$ Stem cells have the following capabilities to perform different treatment for the patients:

- Alzheimer disease

- Heart infarction

- Restoration of vision

- Diabetes

- Formation of blood cells

- Treatment of brain injury

- Hearing

- Heart tissue

- Dentistry

- Orthopaedics

- Biomedical research

- Crohn,s disease

- Development of a complex organism

- Understanding how disease occurs

- Muscle repair

3D printing technology uses a specific type of materials to develop different biomedical devices and bionic organs. It creates neuronal spinal cord scaffold using stem cells. Cells are further printed (grown) by introducing them into the scaffold. The printing of living tissue is quickly done with stem cells using bioink. ${ }^{31,32}$ This bioink consists of different polymer components. Inkjet 3D printers are available to different types of tissue and cell printing. Silk bio-ink is used to create advanced tissue engineering using 3D printing technologies. It is an innovative way to create bone and other body parts that can be further implanted easily in patients.

\section{Different applications of stem cells through 3D printing}

3D printing allows printing of cells which can survive and explore emerging opportunities in today's medical fields. Printed tissues are implanted in living joints for the replacement of the damaged part. 3D printed stem cells are helpful for damaged/injured tissue. The researcher used human cells to create bone tissue engineering. ${ }^{33}$ This technology is successfully used to create human organs from stem cells. This technology is also applicable for veterinary field. ${ }^{34}$ Table 1 discusses different applications of stem cells through 3D printing.

3D printed stem cells having great potential to print skin for the burn patient. These provide innovative development in regenerative medicine and the fabrication of artificial organs. ${ }^{68-72}$ Stem cells are helpful to produce biological components, customised body parts and treatment of chronic heart disease. ${ }^{73-75}$ It is used for the treatment of spinal cord injury; fabrication of customised patient face, ear, jaw bone, teeth and treatment of a blind person. ${ }^{76-78}$

\section{Discussion}

3D printing allows cost-effective and efficient manufacturing of intricate and sophisticated designs. Scientists develop a new bioink to fabricate complex tissue for surgical implants. 3D printing is a new way to make bone and body part for implanted in the patient body. This technology is already revolutionized in medical field for prosthetics and other medical parts. These 3D stems cells are used in scaffold by which human tissue and organs can grow as per the requirement and fulfil the challenge. Now, it is introduced into other therapy areas to print different live tissues and cells using bio-inks. This technology is successfully used to develop replicate human ears helpful for reconstructive surgery. It used specialised bio-ink to print human ear. This bio-ink uses stem cells for the growth of the external human ear. For the clinical trial, surgeons use stem cells from human tissue. These cells are used for making ear cartilage with excellent biological properties. 3D printing technologies create biological implants as per match of patient anatomy. This is used to create facial features using stem cells. It provides a new solution to health to improve the life of the patient. This technology is capable of delivering practical solutions and helping solve different clinical challenges. Now, researchers can easily create custom corneas, which can perfectly suit and match for the individual patient. These 3D printed corneas can further be tested before transplants. 3D printing is an advanced technology used to print living limb, as it provides the ability to recreate complex cell and help fabricate tissue. The patient-specific heart tissue is easily created from biological materials and human cells. These are made up of sugar and protein helpful to print complex tissue models using 3D printing.

\section{Limitations}

Sometimes stem cells have a high rejection rate and can cause serious health problems. These are not suitable for tumour and cannot change different cell tissues. The treatment using stem cells is a costly process which is not affordable by the typical medical organisation. Ethics of research is another limitation in the entire process. There are different types of 3D printing technologies available in the market, each having their respective advantages and limitations. There are lots of general limitations of $3 \mathrm{D}$ printing. An accurate CAD model is required to create an accurate part. The surface texture of a printed part is too rough and having low strength as compared to the traditional manufacturing method. Implants manufactured by this technology required post-processing which increase the cost. This technology is only suitable for customisation, not for the mass production system. The machine cost and the requirement of highly skilled manpower are also the main limitations of this technology. Further, there is a lack of structural stability during fabrication of complex, human-scale tissues.

\section{Future scope}

In future, the bioink with stem cells could be used for multiple applications, both for modelling and transplantation. Researchers add chemical reagents in bioinks as to generate differentiated cells. 3D 
printing will be used for organ replacement, and engineering personalised tissue. This technique will combine biomaterial scaffolds and cells printing for rebuilding damaged tissue. For engineering neural tissues, human induced pluripotent stem cells play an important role. This technology will be used for various biomedical applications. It can easily prepare human mesenchymal stromal cells for the reconstruction of knee joints. In future, this technology will be used to create any heterogeneous tissue regeneration. 3D printing will be also helpful for the precise treatment of spinal cord injuries as compared to the traditional method. It will easily create any customised 3D spinal cords and incorporated into a living organism. In future, this innovative technique of stem cells has huge potential for patients.

\section{Conclusion}

In future, body parts can be fabricated from stem cells using an appropriate 3D printer. 3D printed stem cells provide a flexible motion to the tissues, joints like shoulder or knee. Stem cells are in the form of ink, which can be injected as per the requirements of functional organs using a 3D printer. This technology is applicable to the treatment of the injury. Whereas the newly applied stem cells are further helpful to replace the injured tissue. 3D printing can now easily create transparent human organs which could pave the way to print 3D body parts like kidneys for transplants. It can print detailed organs like blood vessel at a specific location of the cell. This technology plays a significant role to print scaffold for an organ. Stem cells can grow body parts which are damaged during injury or disease. Scientists are trying to overcome this challenge of cultivating cells to provide the particular shape of organ or tissue. In future, this 3D printing technology will overcome the challenges of repair and replacement of tissues and organs as per patient requirement using stem cells.

\section{Declaration of competing interest}

None.

\section{References}

1. Feng KC, Pinkas-Sarafova A, Ricotta V, et al. The influence of roughness on stem cell differentiation using 3D printed polylactic acid scaffolds. Soft Matter. 2018;14:9838-9846.

2. Tao O, Kort-Mascort J, Lin Y, et al. The applications of 3D printing for craniofacial tissue engineering. Micromachines. 2019;10(7):480. https://doi.org/10.3390/ mi10070480.

3. He Y, Yang F, Zhao H, Gao Q, Xia B, Fu J. Research on the printability of hydrogels in 3D bioprinting. Sci Rep. 2016;6:29977. https://doi.org/10.1038/srep29977.

4. Javaid M, Haleem A. Additive manufacturing applications in medical cases: a literature-based review. Alexandria J Med. 2018;54(4):411-422.

5. Gruene M, Deiwick A, Koch L, et al. Laser printing of stem cells for biofabrication of scaffold-free autologous grafts. Tissue Eng C Methods. 2011;17:79-87.

6. Kahl M, Gertig M, Hoyer P, Friedrich O, Gilbert DF. Ultra-low-cost 3D bioprinting: modification and application of an off-the-shelf desktop 3D-printer for biofabrication. Front Bioeng Biotechnol. 2019;7:184. https://doi.org/10.3389/fbioe.2019.00184.

7. Gómez-Ciriza G, Hussain T, Gómez-Cía T, Valverde I. Potential of 3D-printed models in planning structural interventional procedures. Intervent Cardiol. 2015;7:1-5.

8. Roskies M, Jordan JO, Fang D, et al. Improving PEEK bioactivity for craniofacial reconstruction using a 3D printed scaffold embedded with mesenchymal stem cells. $J$ Biomater Appl. 2016;31:132-139.

9. Park SH, Choi Y-J, Moon SW, et al. Three-dimensional bio-printed scaffold sleeves with mesenchymal stem cells for enhancement of tendon-to-bone healing in anterior cruciate ligament reconstruction using soft-tissue tendon graft. Arthroscopy. 2018;34(1):166-179.

10. Bell L, Devaney S. Gaps and overlaps: improving the current regulation of stem cells in the UK. J Med Ethics. 2007;33(11):621-622.

11. Kumar SA, Delgado M, Mendez VE, Joddar B. Applications of stem cells and bioprinting for potential treatment of diabetes. World J Stem Cell. 2019;11(1):13-32.

12. Kim DH, Beebe DJ, Levchenko A. Micro-and nanoengineering for stem cell biology: the promise with a caution. Trends Biotechnol 2011;29(8):399-408.

13. Tappa K, Jammalamadaka U. Novel biomaterials used in medical 3D printing techniques. J Funct Biomater. 2018;9(1):17. https://doi.org/10.3390/jfb9010017.

14. Kilian KA, Bugarija B, Lahn BT, Mrksich M. Geometric cues for directing the differentiation of mesenchymal stem cells. Proc Natl Acad Sci USA. 2010;107:4872-4877.

15. Hsieh FY, Lin HH, Hsu S. 3D bioprinting of neural stem cell-laden thermoresponsive biodegradable polyurethane hydrogel and potential in central nervous system repair.
Biomaterials. 2015;71:48-57.

16. Adamzyk C, Kachel P, Hoss M, et al. Bone tissue engineering using polyether ketone scaffolds combined with autologous mesenchymal stem cells in a sheep calvarial defect model. J Cranio-Maxillo-Fac Surg Off Publ Eur Assoc Cranio-Maxillo-Fac Surg. 2016;44:985-994.

17. Negi S, Dhiman S, Sharma RK. Basics and applications of rapid prototyping medical models. Rapid Prototyp J. 2014;20:256-267.

18. Chadha A, UlHaq M, Raina A, Singh R, Penumarti N, Bishnoi M. Effect of fused deposition modelling process parameters on mechanical properties of 3D printed parts. World J Eng. 2019. https://doi.org/10.1108/WJE-09-2018-0329.

19. Javaid M, Haleem A. Additive manufacturing applications in orthopaedics: a review. $J$ Clin Orthop Trauma. 2018;9(3):202-206.

20. Haleem A, Javaid M, Khan RH, Suman. 3D printing applications in bone tissue engineering. J Clin Orthop Trauma. 2019. https://doi.org/10.1016/j.jcot.2019.12.002.

21. Javaid M, Haleem A. Industry 4.0 applications in medical field: a brief review. Curr Med Res Pract. 2019;9(3):102-109.

22. Haleem A, Javaid M, Vaish A, Vaishya R. Three-Dimensional-printed polyether ether ketone implants for orthopedics. Indian J Orthop. 2019;53(2):377-379.

23. Lobo SE, Glickman R, da Silva WN, Arinzeh TL, Kerkis I. Response of stem cells from different origins to biphasic calcium phosphate bioceramics. Cell Tissue Res. 2015;361:477-495

24. Ouyang L, Yao R, Mao S, Chen X, Na J, Sun W. Three-dimensional bioprinting of embryonic stem cells directs highly uniform embryoid body formation. Biofabrication. 2015;7:044101.

25. Kjar A, Huang Y. Application of micro-scale 3D printing in pharmaceutics. Pharmaceutics. 2019;11(8):390. https://doi.org/10.3390/pharmaceutics11080390.

26. Das S, Pati F, Choi YJ, et al. Bioprintable, cell-laden silk fibroin-gelatin hydrogel supporting multilineage differentiation of stem cells for fabrication of three-dimensional tissue constructs. Acta Biomater. 2015;11:233-246.

27. Lei M, Wang X. Biodegradable polymers and stem cells for bioprinting. Molecules. 2016;21(5):539

28. Haleem A, Javaid M. Polyether ether ketone (PEEK) and its 3D printed implants applications in the medical field: an overview. Clin Epidemiol Glob Health. 2019;7(4):571-577.

29. Javaid M, Haleem A. 4D printing applications in medical field: a brief review. Clin Epidemiol Glob Health. 2019;7(3):317-321.

30. Zhang F, Li C, Wang Z, Zhang J, Wang Y. Multimaterial 3D printing for arbitrary distribution with nanoscale resolution. Nanomaterials (Basel). 2019;9(8):1108. https://doi.org/10.3390/nano9081108.

31. AhnSH, Lee HJ, Lee JS, Yoon H, Chun W, Kim GH. A novel cell-printing method and its application to hepatogenic differentiation of human adipose stem cell-embedded mesh structures. Sci Rep. 2015;5:13427. https://doi.org/10.1038/srep13427.

32. Haleem A, Javaid M. 3D scanning applications in medical field: a literature-based review. Clin Epidemiol Glob Health. 2019;7(2):199-210.

33. Wang X. Spatial effects of stem cell engagement in 3D printing constructs. J Stem Cell Res Rev Rep. 2014;1(2):5-9.

34. Haleem A, Javaid M, Suman R. 3D printing applications for veterinary field. Indian $J$ Anim. Health. 2019;58(2):171-173.

35. Blaeser A, Duarte Campos DF, Puster U, Richtering W, Stevens MM, Fischer H. Controlling shear stress in 3D bioprinting is a key factor to balance printing resolution and stem cell integrity. Adv Healthc Mater. 2016;5:326-333.

36. Haleem A, Javaid M. Polyether ether ketone (PEEK) and its manufacturing of customised 3D printed dentistry parts using additive manufacturing. Clin Epidemiol Glob Health. 2019. https://doi.org/10.1016/j.cegh.2019.03.001.

37. Wang X. Bioartificial organ manufacturing technologies. Cell Transplant. 2019;28(1):5-17.

38. Faulkner-Jones A, Fyfe C, Cornelissen DJ, et al. Bioprinting of human pluripotent stem cells and their directed differentiation into hepatocyte-like cells for the gen eration of mini-livers in 3D. Biofabrication. 2015;7:044102.

39. Nyberg EL, Farris AL, Hung BP, et al. 3D-Printing technologies for craniofacial re habilitation, reconstruction, and regeneration. Ann Biomed Eng. 2017;45(1):45-57

40. Li L, Li Y, Yang L, et al. Polydopamine coating promotes early osteogenesis in 3D printing porous Ti6Al4V scaffolds. Ann Transl Med. 2019;7(11):240. https://doi.org/ 10.21037/atm.2019.04.79.

41. Zhou Y. The recent development and applications of fluidic channels by 3D printing J Biomed Sci. 2017;24(1):80. https://doi.org/10.1186/s12929-017-0384-2.

42. Sharafeldin M, Jones A, RuslingJF. 3D-Printed biosensor arrays for medical diagnostics. Micromachines. 2018;9(8):394. https://doi.org/10.3390/mi9080394.

43. Gao G, Yonezawa T, Hubbell K, Dai G, Cui X. Inkjet-bioprintedacrylated peptides and PEG hydrogel with human mesenchymal stem cells promote robust bone and cartilage formation with minimal printhead clogging. Biotechnol J. 2015;10:1568-1577.

44. Yang E, Miao S, Zhong J, Zhang Z, Mills DK, Zhang LG. Bio-based polymers for 3D printing of bioscaffolds. Polym Rev. 2018;58(4):668-687.

45. Yeo M, Lee JS, Chun W, Kim GH. An innovative collagen-based cell-printing method for obtaining human adipose stem cell-laden structures consisting of core-sheath structures for tissue engineering. Biomacromolecules. 2016;17:1365-1375.

46. Xu W, Wang X, Sandler N, Willför S, Xu C. Three-Dimensional printing of woodderived biopolymers: a review focused on biomedical applications. ACS Sustainable Chem Eng. 2018;6(5):5663-5680.

47. Goldshmid R, Seliktar D. Hydrogel modulus affects proliferation rate and pluripotency of human mesenchymal stem cells grown in three-dimensional culture. ACS Biomater Sci Eng. 2017;3:3433-3446.

48. Haleem A, Javaid M. Role of CT and MRI in the design and development of orthopaedic model using additive manufacturing. J Clin Orthop Trauma. 2018;9(3):213-217.

49. Chien KB, Shah RN. Novel soy protein scaffolds for tissue regeneration: 
materialization characterisation and interaction with human mesenchymal stem cells. Acta Biomater. 2012;8:694-703.

50. YooSJ Thabit O, Kim EK, Ide H, et al. 3D printing in medicine of congenital heart diseases. 3D Print Med. 2015;2(1):3. https://doi.org/10.1186/s41205-016-0004-x.

51. Vashistha R, Kumar P, Dangi AK, Sharma N, Chhabra D, Shukla P. Quest for cardiovascular interventions: precise modeling and 3D printing of heart valves. $J$ Biol Eng. 2019;13:12. https://doi.org/10.1186/s13036-018-0132-5.

52. Gu Q, Tomaskovic-Crook E, Lozano R, et al. Functional 3D neural mini-tissues from printed gel-based bioink and human neural stem cells. Adv Healthcare Mater. 2016;5:1429-1438

53. Placone JK, Engler AJ. Recent advances in extrusion-based 3D printing for biomedical applications. Adv Healthc Mater. 2018;7(8):e1701161https://doi.org/10.1002/ adhm. 201701161.

54. Kamei K. Cutting-edge microfabricated biomedical tools for human pluripotent stem cell research. J Lab Autom. 2013;18(6):469-481.

55. Jamróz W, Szafraniec J, Kurek M, Jachowicz R. 3D printing in pharmaceutical and medical applications - recent achievements and challenges. Pharm Res (N Y). 2018;35(9):176. https://doi.org/10.1007/s11095-018-2454-x.

56. Cidonio G, Glinka M, Dawson JI, Oreffo ROC. The cell in the ink: improving bio fabrication by printing stem cells for skeletal regenerative medicine. Biomaterials. 2019;209:10-24

57. Lou YR, Kanninen L, Kuisma T, et al. The use of nanofibrillar cellulose hydrogel as a flexible three-dimensional model to culture human pluripotent stem cells. Stem Cell Dev. 2014;23(4):380-392

58. O'Brien CM, Holmes B, Faucett S, Zhang LG. Three-dimensional printing of nanomaterial scaffolds for complex tissue regeneration. Tissue Eng Part B Rev. 2015;21(1):103-114.

59. Kwon SG, Kwon YW, Lee TW, Park GT, Kim JH. Recent advances in stem cell therapeutics and tissue engineering strategies. Biomater Res. 2018;22:36. https://doi.org/ 10.1186/s40824-018-0148-4.

60. Ouyang LL, Yao R, Zhao Y, Sun W. Effect of bioink properties on printability and cell viability for 3D bioplotting of embryonic stem cells. Biofabrication. 2016;8. https:// doi.org/10.1088/1758-5090/8/3/035020.

61. Lin Y, Umebayashi M, Abdallah MN, et al. Combination of polyether Ether ketone scaffold and human mesenchymal stem cells from temporomandibular joint synovial fluid enhances bone regeneration. Sci Rep. 2019;9:472. https://doi.org/10.1038/ s41598-018-36778-2.

62. Tasoglu S, Demirci U. Bioprinting for stem cell research. Trends Biotechnol. 2013;31(1):10-19.

63. Javaid M, Haleem A. 3D printed tissue and organ using additive manufacturing: an overview. Clin Epidemiol Glob Health. 2019. https://doi.org/10.1016/j.cegh.2019.12. 008.

64. Zhuang P, Ng WL, An J, Chua CK, Tan LP. Layer-by-layer ultraviolet assisted extrusion-based (UAE) bioprinting of hydrogel constructs with high aspect ratio for soft tissue engineering applications. PloS One. 2019;14(6):e0216776https://doi.org/10. 1371/journal.pone.0216776.

65. Javaid M, Haleem A. Current status and applications of additive manufacturing in dentistry: a literature-based review. J Oral Biol Craniofac Res. 2019;9:179-185.

66. Liao W, Xu L, Wangrao K, Du Y, Xiong Q, Yao Y. Three-dimensional printing with biomaterials in craniofacial and dental tissue engineering. Peer $J$. 2019;7:e7271https://doi.org/10.7717/peerj.7271.

67. Yi HG, Choi YJ, Jung JW, et al. Three-dimensional printing of a patient-specific engineered nasal cartilage for augmentative rhinoplasty. J Tissue Eng. 2019;10. https://doi.org/10.1177/2041731418824797 2041731418824797.

68. Xu H, Cai S, Sellers A, Yang Y. Intrinsically water-stable electrospun three-dimensional ultrafine fibrous soy protein scaffolds for soft tissue engineering using adiposederived mesenchymal stem cells. RSC Adv. 2014;4:15451-15457.

69. Awasthi S, Verma T, Agarwal M, Singh JV, Srivastava NM, Nichterd M. Developing effective health communication messages for community-acquired pneumonia in children under five years of age: a rural North Indian qualitative study. Clin Epidemiol Glob Health. 2017;5:107-116.

70. Ma Y, Ji Y, Huang G, Ling K, Zhang X, Xu F. Bioprinting 3D cell-laden hydrogel microarray for screening human periodontal ligament stem cell response to extracellular matrix. Biofabrication. 2015;7:044105https://doi.org/10.1088/1758-5090/ 7/4/044105.

71. Theodoridis K, Aggelidou E, Vavilis T, et al. Hyaline cartilage next-generation implants from adipose tissue-derived mesenchymal stem cells: comparative study on 3D-printed polycaprolactone scaffold patterns. J Tissue Eng Regen Med. 2019;13:342-355.

72. Javaid M, Haleem A. Current status and challenges of Additive manufacturing in orthopaedics: an overview. J Clin Orthop Trauma. 2019;10(2):380-386.

73. Lin K, Sheikh R, Romanazzo S, Roohani I. 3D printing of bioceramic scaffolds-barriers to the clinical translation: from promise to reality, and future perspectives. Materials. 2019;12(17):2660. https://doi.org/10.3390/ma12172660.

74. Haleem A, Javaid M. Enablers, barriers and critical success factors for effective adoption of colour-jet 3D printing technology. J Ind Integrat Manag. 2019. https:// doi.org/10.1142/S242486221950009X.

75. Gao G, Schilling AF, Hubbell $\mathrm{K}$, et al. Improved properties of bone and cartilage tissue from 3D inkjet-bioprinted human mesenchymal stem cells by simultaneous deposition and photocrosslinking in PEG-GelMA. Biotechnol Lett. 2015;37:2349-2355

76. Javaid M, Haleem A, Kumar L. Current status and applications of 3D scanning in dentistry. Clin Epidemiol Glob Health. 2019;7(2):179-185.

77. Wang Q, Han G, Yan S, Zhang Q. 3D printing of silk fibroin for biomedical applications. Materials. 2019;12(3):504. https://doi.org/10.3390/ma12030504.

78. Jang J, Park HJ, Kim SW, et al. 3D printed complex tissue construct using stem cell laden decellularised extracellular matrix bioinks for cardiac repair. Biomaterials. 2017;112:264-274. 